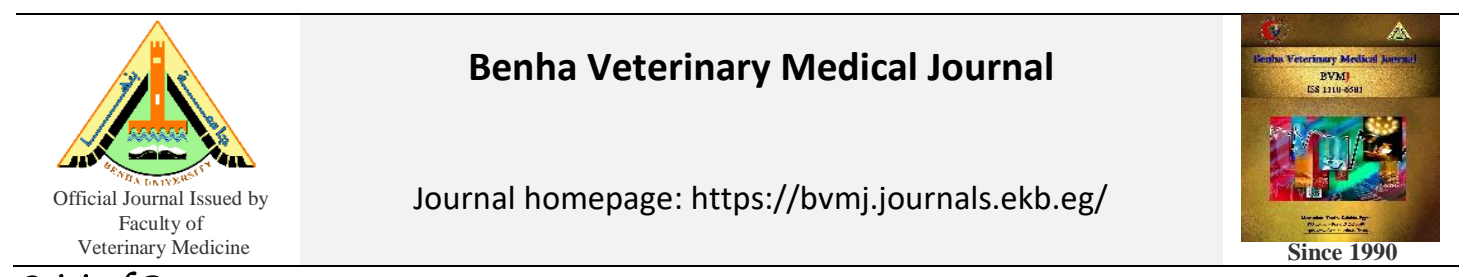

Original Paper

\title{
Attenuating effect of spirulina platensis and alpha-lipoic acid against aspartame induced oxidative stress and brain damage in rabbits
}

\author{
Samy A. Hussein', Yakout A. Al-Senosy', Mahamoud M. Arafa² and Hamam A. Ebead, ${ }^{2}$ \\ ${ }^{1}$ Department of Biochemistry, Faculty of Veterinary Medicine, Benha University, Egypt. \\ ${ }^{2}$ Department of Biochemistry and Food Deficiency, Animal Health Research Institute( AHRI), Agriculture Research Center, \\ Dokki, Giza, Egypt.
}

\begin{tabular}{|c|c|}
\hline ARTICLE INFO & ABSTRACT \\
\hline $\begin{array}{l}\text { Keywords } \\
\text { Alpha-lipoic acid } \\
\text { Aspartame } \\
\text { DNA damage } \\
\text { Oxidative stress } \\
\text { Spirulina platensis }\end{array}$ & $\begin{array}{l}\text { This study was conducted to evaluate the possible protective effect of Spirulina and alpha- } \\
\text { lipoic acid against aspartame induced oxidative stress and brain damage in rabbits. Forty-two } \\
\text { white male New-Zealand Rabbits were classified into seven groups. Group I(Control) received } \\
\text { no drugs. Group II (ASP) received aspartame ( } 250 \mathrm{mg} / \mathrm{kg} \text { b. wt./day). Group III (LA)received } \\
\text { alpha-lipoic acid ( } 100 \mathrm{mg} / \mathrm{kg} \mathrm{b} \text {. wt./day). Group IV (SPir) received spirulina platensis ( } 1500 \\
\mathrm{mg} / \mathrm{kg} \text {. b. wt./day). Group V (ASP+ LA) received aspartame ( } 250 \mathrm{mg} / \mathrm{kg} \text { b. wt.) and alpha- } \\
\text { lipoic acid ( } 100 \mathrm{mg} / \mathrm{kg} \mathrm{b.} \mathrm{wt.).} \mathrm{Group} \mathrm{VI} \mathrm{(ASP+} \mathrm{Spir)} \mathrm{received} \mathrm{aspartame} \mathrm{(} 250 \mathrm{mg} / \mathrm{kg} \text { b.wt.) } \\
\text { and spirulina platensis ( } 1500 \mathrm{mg} / \mathrm{kg} \text { b. wt.). Group VII (ASP+ALP+Spir) received aspartame } \\
\text { ( } 250 \mathrm{mg} / \mathrm{kg} \text { b.wt.), alpha-lipoic acid ( } 100 \mathrm{mg} / \mathrm{kg} \text { b. wt.) and Spirulina platensis (1500 mg/kg } \\
\text { b. wt.) for } 8 \text { weeks. At the end of experiment, brain tissues were collected and analyzed for L- } \\
\text { malondialdehyde(L-MDA), superoxide dismutase (SOD), reduced glutathione (GSH), gene } \\
\text { expression of tumor necrosis factor alpha (TNF- } \alpha \text { )and caspase } 3 \text {, and DNA damage. The results } \\
\text { showed a significant up-regulation of TNF- } \alpha \text { and caspase } 3 \text { gene expression level, marked } \\
\text { increase in L-MDA and DNA damage, and a marked decrease in SOD activity and GSH } \\
\text { concentration in ASP groupwhen compared with control group. Co-administration of spirulina } \\
\text { and alpha-lipoic acid protected aspartame induced brain damage and caused a significant } \\
\text { improvement of all previous parameters and attenuated DNA changes. Conclusively, Spirulina } \\
\text { platensis and alpha-lipoic acid exerted a protective effect against DNA damage and oxidative } \\
\text { stress in the brain of aspartame usage through free radical scavenging and anti-inflammatory } \\
\text { activities as well as regenerating endogenous antioxidants defense system mechanisms. }\end{array}$ \\
\hline
\end{tabular}

\section{INTRODUCTION}

Aspartame (L-aspartyl-L-phenylalanine methyl ester ASP) is one of the most widely used artificial sweeteners. It is composed of substances normally found in food, feed of the diet, and the body i.e. the amino acids aspartic acid and phenylalanine and the alcohol methanol the metabolism of ASP provides approximately $4 \mathrm{kcal} / \mathrm{g}$ of energy (Gouge et al., 2004). However, this energy is negligible as the high intensity sweetening power of ASP (approximately 200 sweeter than sucrose by weight means that little is needed to be added to food to achieves sweetness (Magnuson et al., 2007).After oral administration to humans and experimental animals, ASP is rapidly and completely metabolized to aspartic acid, phenylalanine and methanol. Aspartic acid is a highly excitatory neurotransmitter (Krebs, 1992). However, the blood-brain barrier precludes influx of aspartate into the brain (Pardridge, 1979). The neutral amino acid phenylalanine is the precursor of the two brain catecholamine neurotransmitters, dopamine and norepinephrine. When phenylalanine concentration in blood plasma is elevated, the uptake into the brain increases at the expense of that of the other neutral amino acids. Thus, an increased phenylalanine level may affect brain levels of dopamine and norepinephrine and influence brain functions (Harper,1984).In addition, the increased uptake of phenylalanine might reduce the uptake of tryptophan (precursor of serotonin) and hence indirectly influence the biosynthesis level of serotonin in the brain, and affecting brain function (Pardridge, 1986). The methanol is oxidized in the liver to formaldehyde which is further oxidized to formic acid. Formic acid is converted to $\mathrm{CO}_{2}$ and water, via formation of 10-formyl tetra hydro folate (Barceloux et al., 2000). However, consumption of $50 \mathrm{mg}$ ASP/ $\mathrm{kg}$ body weight would result in ingestion of $5 \mathrm{mg}$ methanol $/ \mathrm{kg}$ body weight (10\% of ASP by weight is methanol). Additionally, consumption of ASP has been reported to be responsible for neurological and behavioral disturbances in sensitive individuals. The adverse neurological effects such as headaches, insomnia and seizures may be attributed to the alterations in regional brain concentrations of catecholamine (Coulombe and Sharma, 1986).

Oxidative stress is related to the pathogenesis of some conditions affecting the central nervous system (CNS), such

* Corresponding author: Hamam A. Ebead. Department of Biochemistry and Food Deficiency, Animal Health Research Institute ( AHRI), Agriculture Research Center, Dokki, Giza, Egypt. 
as various neurodegenerative disorders (Halliwell and Gutteridge 1999).

Compared with other organs, brain is especially vulnerable to oxidative stress due to the high utilization of oxygen, the large amount of easily oxidizable polyunsaturated fatty acids, the abundance of redox-active transition metal ions and the relative reduction of antioxidant defense systems (Butterfield and Stadtman, 1997). Antioxidant system is involved in the defense system against free radical mediated tissue or cellular damage. There is enzymatic antioxidant system which includes a family of glutathione-dependent enzymes, superoxide dismutase and catalase (Chaudiere and Ferrari-iliou, 1999), in addition to the non-enzymatic (glutathione and uric acid) antioxidant. Moreover, GSH acts as the non-enzymatic anti-oxidative defense because it reacts with nitric oxide and protects the cellular system against the toxic effects of lipid peroxidation which produced from induced aspartame.

Tumor necrosis factor alpha (TNF- $\alpha$ ) is an inflammatory cytokine secreted by macrophages, neutrophils, T-cells and natural killer (NK) cells. It plays a major role in growth regulation, inflammation, tumor genesis, tumor metastasis and autoimmune diseases. Moreover, TNF- $\alpha$ is contributed to the manifestation of the pathological and systemic inflammatory response and ultimately to the development of organ failure. Additionally, Soffritti et al. (2010) demonstrates that chronic ASP consumption $(75 \mathrm{mg} / \mathrm{kg}$ b.wt./day) for 90 days significantly increased brain damage associated brain markers (BDNF, COX-2 andPGE2) and elevated the production of cerebral cortex cytokines, IL-6 and TNF-a, respectively. Moreover, the same exposure reduced GSH levels, enhanced TNO production as well as ROS generation and LPO of ASP-result in apoptosis. ASP can be triggered by signals arising from the activation of death receptor-mediated (extrinsic) or mitochondrialmediated (intrinsic) signaling pathways. Extrinsic apoptotic signaling involves the activation of cell surface death receptors belonging to the protein family of tumor necrosis factor receptors Fas (Itoh and Nagata, 1993). The binding of Fas receptor with its cognate ligand, Fas L, can result in activation of caspase 8, activating downstream effector caspases (e.g., caspases 3, 6, and 7), resulting in apoptosis (Boldin et al., 1995). Cytochrome c accelerates the activation of caspase 9, initiating a downstream caspase cascade, which ultimately leads to cell death. AIF induces apoptosis via a caspase-independent pathway when cells experience serious oxidative stress. Beg et al.(1993) demonstrated that, cytokine, TNF- $\alpha$, mediates early-stage responses of inflammation by regulating the production of other cytokines, including interleukin-1(IL-1), interleukin10 (IL-10) and IL-6. Because TNF- $\alpha$ is the main mediator of several inflammatory toxic responses to chemicals, it represent promising target for the prevention of uncontrolled inflammation. TNF- $\alpha$ has also been reported to induce nuclear factor-kappa beta $(\mathrm{NF}-\kappa \beta)$ production and this protein is inhibited by the presence of antioxidants.

Alpha Lipoic Acid acts as coenzyme of pyruvate and it protects against oxidative stress both in peripheral tissues and central nervous system (Winiarska et al., 2008). Additionally, Spirulina strongly induces antioxidant enzyme activity, helps to prevent lipid peroxidation and DNA damage, and scavenges free radicals (Abdelkhalek et al., 2015). Accordingly, the present study aims to investigate the harmful effect of aspartame exposure on brain of rabbits, and the potential ameliorating role of Spirulina platensis and alpha-lipoic acid against aspartame induced oxidative stress and brain damage in rabbits were also evaluated.

\section{MATERIAL AND METHODS}

\subsection{Experimental Animals.}

Forty-two white male New-Zealand Rabbits of 4-6 weeks old age and average body weight $800-1200 \mathrm{~g}$ were used in the experimental investigation of this study. Rabbits were obtained from Laboratory Animals Research Center Faculty of Veterinary Medicine, Benha University. Rabbits were housed in separated metal cages ( 6 per cage) and they were kept on a well-balanced ration and fresh clean drinking water ad-libitum. Rabbits were kept at a constant environmental and nutritional condition throughout the whole period of experiment. All rats were left for 15 days for acclimatization before the beginning of the experiment.

\subsection{Chemicals and antioxidants}

All chemicals were of analytical grade obtained from standard commercial suppliers.

a. Aspartame was purchased from Al-Ameriya pharma company, Egypt. in the form of tablets each tablet contains $20 \mathrm{mg}$ of aspartame.

b. Spirulina platensis microalgae blue green powder was obtained from Cairo National Research Center-DokkiEgypt. Spirulina was freshly prepared by dissolving in distilled water and administered orally using stomach tube in a daily dose of $1500 \mathrm{mg} / \mathrm{kg}$ body weight (Collaet al., 2008).

c.Alpha lipoic acid (Thioctic acid) ${ }^{\circledR}$; Synonyms: thioctic acid, 6, 8-dithiooctanoic acid, 1, 2dithiolane-3-pantanoic acid. manufactured by Eva pharma, Egypt. DL- $\alpha$-Lipoic acid was given orally in a daily dose of $100 \mathrm{mg} / \mathrm{kg}$ body weight of rabbits according to (Şehirli et al., 2008).

after dissolving the content of each capsule $(600 \mathrm{mg})$ in propylene glycol (El-Nasr Pharmaceutical Chemicals Co. Abu Zaabal, Egypt).

\subsection{Experimental design:}

After acclimatization to the laboratory conditions, the animals were randomly classified into seven groups, 6 rabbits each, placed in individual cages and classified as following:

- Control group (Group I):rabbits were given distilled water and served as control normal group.

- Alpha Lipoic acid group (Group II): Rabbits were administered alpha lipoic acid orally $(100 \mathrm{mg} / \mathrm{kg}$ b.wt./day).

- Spirulina group (Group III): Rabbits were administered Spirulina (1500 mg/kg b.wt./day).

- Aspartame group (Group VI): Rabbits were administered aspartame orally ( $250 \mathrm{mg} / \mathrm{kg}$ b.wt./day).

- Aspartame and alpha lipoic acid group (Group V): Rabbits were administered aspartame orally (250 $\mathrm{mg} / \mathrm{kg}$ b.wt./day) and alpha lipoic acid $(100 \mathrm{mg} / \mathrm{kg}$ b.wt./day).

- Aspartame and Spirulina group (Group VI): Rabbits were administered aspartame orally $(250 \mathrm{mg} / \mathrm{kg}$ b.wt./day) and Spirulina (1500 mg/kg b.wt./day).

- Aspartame, alpha lipoic acid and Spirulina group (Group VII): Rabbits were administered aspartame (250 mg/kg b.wt/day), Spirulina (1500 mg/kg b.wt/day) 
and lipoic Acid (100 mg/kg b.wt/day), once daily by oral gavage for a period of 8 weeks.

\subsection{Sampling:}

Brain specimens were collected from all animal in each group (control and experimental groups) once after the end of 8 weeks.

2.4.1. Tissue samples for biochemical analysis:

At the end of the experiment the rabbits brain tissues were isolated immediately and weighed. Brain tissue was divided into 2 parts. One part was cleaned by rinsing with cold saline and stored at $-20^{\circ} \mathrm{C}$ for subsequent biochemical analysis. All brain samples were analyzed for the determination of reduced Glutathione (GSH), superoxide dismutase (SOD), and L-malondialdehyde (L-MDA) and the second part was kept at $-80^{\circ} \mathrm{C}$ for molecular analysis.

2.4.2.Brain tissue preparation for biochemical analysis:

Brain tissues were cut, weighed and minced into small pieces, homogenized with a glass homogenizer in 9 volume of ice-cold $0.05 \mathrm{mM}$ potassium phosphate buffer $(\mathrm{pH} 7.4)$ to make $10 \%$ homogenates. The homogenates were centrifuged at $6000 \mathrm{rpm}$ for 15 minutes at $4{ }^{\circ} \mathrm{C}$ then the resultant supernatant was used for the determination of the following parameters: L-MDA and SOD. About $0.2 \mathrm{~g}$ of brain tissues were minced into small pieces homogenized with a glass homogenizer in $0.4 \mathrm{ml}$ of $25 \%$ metaphosphoric acid (MPA), (Ref. No.: 253-433- 4, Sigma-Aldrich, Germany), then $1.4 \mathrm{~mL}$ of distilled water was added , mixed, incubated for 1 hour and centrifuged for $10 \mathrm{~min}$ at $3000 \mathrm{rpm}$ then the clear supernatant was removed and used for determination of GSH concentration.

\subsubsection{Brain tissue for molecular analysis:}

Brain tissue was immediately excised and frozen in liquid nitrogen and then in $-80^{\circ} \mathrm{C}$ until used for determination of DNA damage using comet assay, caspase-3 and tumor necrosis factor alpha (TNF- $\alpha$ ) gene expression analysis by qPCR.

\subsection{Analysis:}

2.5.1. Biochemical analysis: Brain tissue L-MDA, superoxide dismutase (SOD) and reduced glutathione (GSH) were determined according to the method adapted by Ohkawa et al. (1979), Nishikimi et al. (1972) and Beutler et al. (1963), respectively.

\subsubsection{Molecular analysis.}

Total RNA was isolated from brain tissue of rabbits using RNeasy Mini Kit (Thermo Scientific, Fermentas, \#K0731) according to the manufacturer's protocol. Following determination of RNA concentration and purity by Quawellnanodrop Q5000 (USA), $5 \mathrm{mg}$ of total RNA from each sample was reverse transcribed using Quant script reverse transcriptase. The produced cDNA was used as a template to determine the relative expression of Caspase3,Tumor necrosis factor alpha (TNF- $\alpha$ ), gene using Step One Plus real time PCR system (Applied Biosystem, USA) and gene specific primers. The reference gene, $\beta$ actin, was used to calculate fold change in target genes expression. The thermal cycling conditions, melting curves temperatures, and calculation of relative expression was done. For the treated groups, assessment of $2-\Delta \Delta \mathrm{Ct}$ determined the fold change in gene expression relative to the control.

Table 1 Forward and reverse primers sequence for real time PCR.
\begin{tabular}{|l|l|l|}
\hline Gene & $\begin{array}{l}\text { Forward primer } \\
(/ 5-----/ 3)\end{array}$ & $\begin{array}{l}\text { Reverse primer } \\
(/ 5----/ 3)\end{array}$ \\
\hline Caspase 3 & GGTATTGAGACAGACAGTGG & CATGGGATCTGTTCTTTGC \\
\hline TNF-a & GCATGATCCGCGACGTGGAA & AGATCCATGCCGTTGGCCAG \\
\hline$\beta$-actin & AAGTCCCTCACCCTCCCAAAAG & AAGCAATGCTGTCACCTTCCC \\
\hline
\end{tabular}

Also, DNA damage was determined by alkaline single-cel gel electrophoresis (comet assay) according to the protocol described by Singh et al. (1988).

\subsection{Statistical analysis:}

The results were expressed as mean \pm SE using SAS computerized program v. 9.2 SAS (2008) program to calculate the analysis of variance. The data were analyzed using one-way ANOVA to determine the statistical significance of differences among groups. Duncan's test was used for making a multiple comparisons within groups for testing the inter-grouping homogeneity. Values were considered statistically significant when $\mathrm{p}<0.05$.

\section{RESULTS}

The obtained results presented in table (2) revealed that oral Aspartame administration to rabbits for 8 weeks resulted in significant increase in L-MDA concentration, decrease of SOD activity and GSH concentration when compared with control normal group. On the other hand, treatment with spirulina and alpha-lipoic acid to aspartame administered rabbits for 8 weeks showed a significant decrease in serum L- MDA level, increase of SOD activity and GSH concentration when compared to aspartame group. Additionally, no significant changes were observed in LMDA concentration, SOD activity and GSH concentration in spirulina and alpha-lipoic acid treated normal rabbit groups when compared to control group.

The obtained results in (Table 3 and Fig. 1,2) revealed significant $(\mathrm{P} \leq 0.05)$ up-regulation of caspase 3 and TNF- $\alpha$ gene expression level in brain of Asp-treated (Asp group) rabbits as compared to the normal control group (group I). In Asp administered rabbits and treated with LA and/ or Spir exhibited a significant down-regulation of caspase 3 and TNF- $\alpha$ gene expression at the following order; Asp+LA+Spir (lowest expression) $<$ Asp+Spir $<$ Asp+LA (highest expression) as compared to Asp group. Additionally, no significant changes in the expression of caspase 3 and TNF- $\alpha$ were noticed among the three control groups (control, LA and Spir).

Comet assay analysis:

Comet assay was performed to assess DNA damage in brain of Asp administered rabbits after treatment by spirulina and/or LA as compared to the control. The results of comet assay presented in figures (3) and tables (4) shown a significant increase in DNA damage $(\mathrm{P}<0.05)$ that was indicated by increase in tail length, tail DNA\% and tail moment was observed in rabbits administrated with aspartame as compared to thecontrol and protective groups. This increased DNA damage was significantly reduced after administration of spirulina alone (Spir ) or in combination with LA, with lowest damage in combined treated group (Asp+LA+Spir). However, nosignificant difference was noticed between G5 (Asp+LA) and G4 (Asp)or among the 
three normal control group (G1 control group, G2 LA and G3 Spir).

\section{DISCUSSION}

Aspartame (E 951) is the most commonly used non-nutritive artificial sweeteners over 100 countries in more than 6000 pharmaceutical products and feed, drugs and including soft drinks, fruit juice, baked goods, chewing gum, candy, puddings, canned foods, ice cream, yogurt, table sweeteners and plenty of other foods and beverages. (Magnuson et al., 2007).

Table 2 Effect of alpha-Lipoic acid and/or Spirulina administrations on brain tissue GSH, L-MDA concentrations and SOD activity in aspartame treated male rabbits

\begin{tabular}{lccc}
\hline Animal groups & $\begin{array}{c}\text { GSH } \\
\text { (ng/g. tissue) }\end{array}$ & $\begin{array}{c}\text { L-MDA } \\
\text { (nmol/g.tissue) }\end{array}$ & $\begin{array}{c}\text { SOD } \\
\text { (U/g.tissue) }\end{array}$ \\
\hline Control & $4.63 \pm 0.17^{\mathrm{a}}$ & $4.27 \pm 027^{\mathrm{e}}$ & $4.27 \pm 0.27^{\mathrm{e}}$ \\
Lipoic acid (LA) & $4.41 \pm 0.19^{\mathrm{a}}$ & $4.36 \pm 0.21^{\mathrm{e}}$ & $4.36 \pm 0.21^{\mathrm{e}}$ \\
Spirulina (Spir) & $4.75 \pm 0.15^{\mathrm{a}}$ & $4.09 \pm 0.30^{\mathrm{c}}$ & $4.09 \pm 0.30^{\mathrm{c}}$ \\
Aspartame (Asp) & $1.51 \pm 0.10^{\mathrm{c}}$ & $9.40 \pm 0.58^{\mathrm{a}}$ & $9.40 \pm 0.58^{\mathrm{a}}$ \\
Asp+LA & $2.84 \pm 0.12^{\mathrm{d}}$ & $7.51 \pm 0.43^{\mathrm{b}}$ & $7.51 \pm 0.43^{\mathrm{b}}$ \\
Asp+Spir & $3.37 \pm 0.10^{\mathrm{c}}$ & $6.32 \pm 0.25^{\mathrm{c}}$ & $6.32 \pm 0.25^{\mathrm{c}}$ \\
Asp+LA+Spir & $3.72 \pm 0.14^{\mathrm{b}}$ & $5.24 \pm 0.22^{\mathrm{d}}$ & $5.24 \pm 0.22^{\mathrm{d}}$ \\
\hline Data are presented as (Mean $\pm \mathrm{SE}$ ). SE $=$ Standard error. Mean values with different
\end{tabular}

superscript letters in the same column are significantly different at $(\mathrm{P} \leq 0.05)$.

Table 3 Effect of alpha-lipoic acid and/or Spirulina administrations on the relative expression of caspase 3 and TNF- $\alpha$ gene in brain tissues of Aspartame treated male rabbits.

\begin{tabular}{|c|c|c|}
\hline Animal Groups & $\begin{array}{c}\text { (Caspase } 3 \text { gene) } \\
\text { Fold change mean } \pm \text { SEM }\end{array}$ & $\begin{array}{c}\text { (TNF- } \alpha \text { gene) } \\
\text { Fold change } \pm \text { SEM }\end{array}$ \\
\hline Control & $1.00 \pm 0.07^{\mathrm{e}}$ & $1.00 \pm 0.08^{\mathrm{d}}$ \\
\hline Lipoic acid (LA) & $1.18 \pm 0.08^{\mathrm{e}}$ & $1.02 \pm 0.09^{\mathrm{d}}$ \\
\hline Spirulina (Spir) & $0.96 \pm 0.1^{\mathrm{e}}$ & $0.93 \pm 0.07^{\mathrm{d}}$ \\
\hline Aspartame (Asp) & $4.82 \pm 0.23^{\mathrm{a}}$ & $3.66 \pm 0.05^{\mathrm{a}}$ \\
\hline Asp $+\mathrm{LA}$ & $3.23 \pm 0.16^{\mathrm{b}}$ & $2.35 \pm 0.11^{\mathrm{b}}$ \\
\hline Asp+Spir & $2.64 \pm 0.09^{c}$ & $1.73 \pm 0.09^{\mathrm{c}}$ \\
\hline Asp+LA+Spir & $1.87 \pm 0.06^{\mathrm{d}}$ & $1.49 \pm 0.08^{\mathrm{c}}$ \\
\hline
\end{tabular}

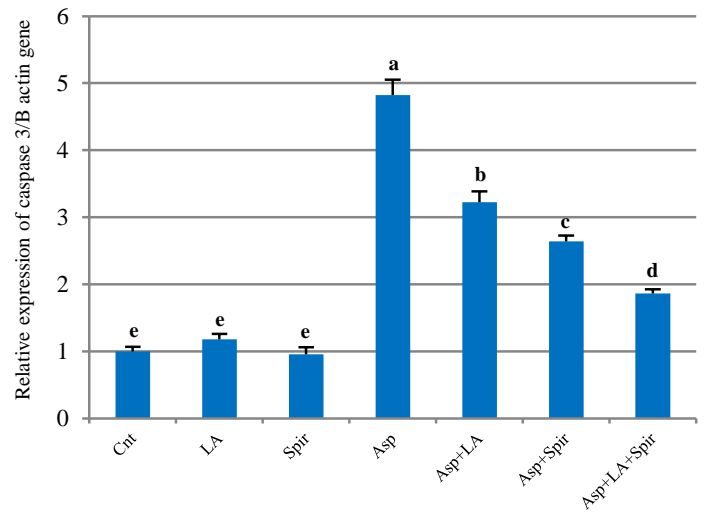

Fig. 1 Graphical presentation of real-time quantitative PCR analysis of the expression of caspase 3 gene in brain tissues of Asp treated rabbits following treatment by alpha-lipoic acid and/or Spirulina

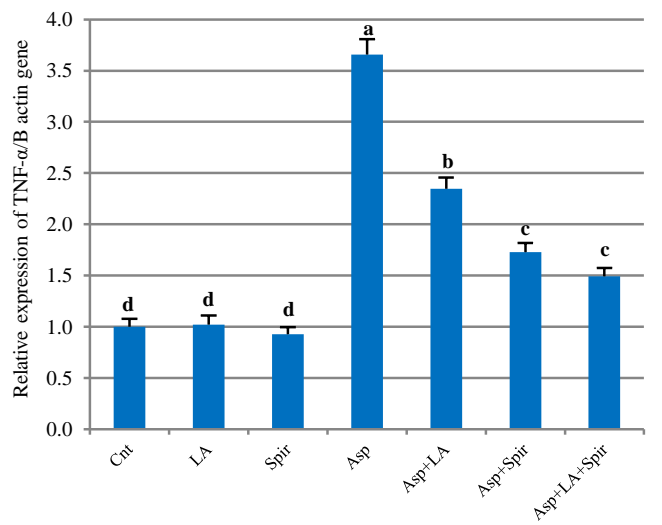

Fig. 2 Graphical presentation of real-time quantitative PCR analysis of the expression of TNF- $\alpha$ gene in brain tissues ofAsp treated rabbits following treatment by alpha-lipoic acid and/or Spirulina.
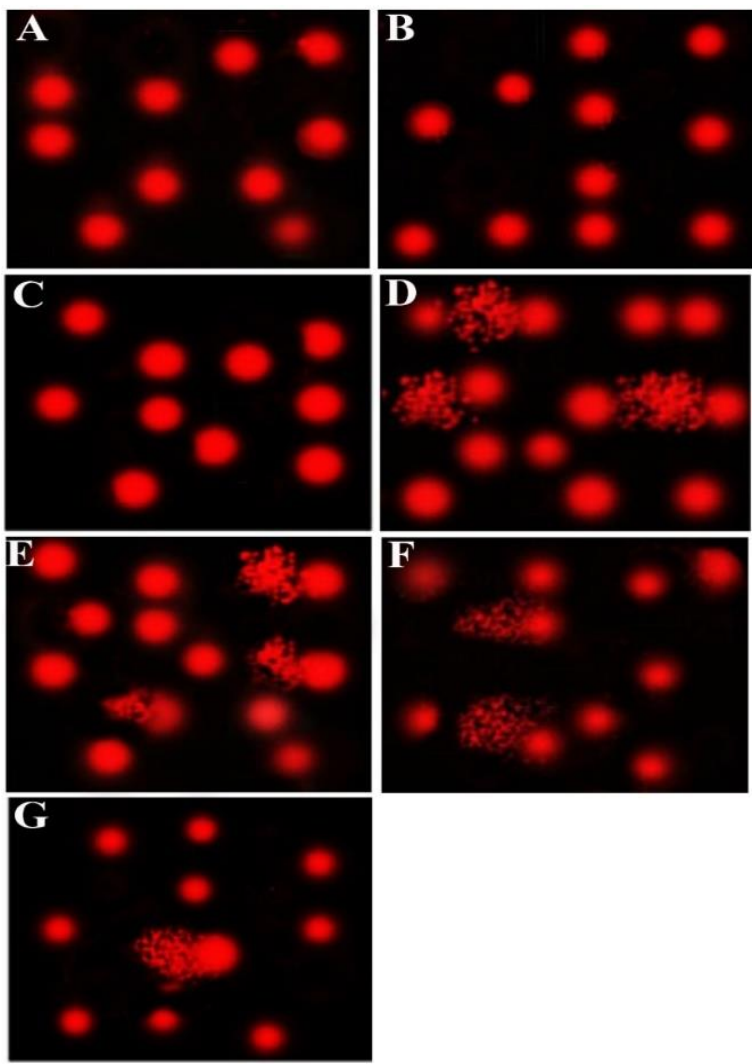

Fig. 3 Photomicrographs representation of DNA damage in brain tissues using comet assay in normal control group (A), group (LA) (B), group (Spir)(C), group (Asp) (D), group $(\mathrm{Asp}+\mathrm{LA})(\mathrm{E})$, group $(\mathrm{Asp}+\mathrm{Spir})(\mathrm{F})$ and group $(\mathrm{Asp}+\mathrm{LA}+\mathrm{Spir})(\mathrm{G})$.

Table 4 Comet assay parameters obtained by image analysis in cells of all rabbit groups after treatment experiment

\begin{tabular}{llllll}
\multicolumn{1}{l}{$\begin{array}{l}\text { Animal } \\
\text { Groups }\end{array}$} & $\begin{array}{l}\text { Tailed } \\
\text { Control }\end{array}$ & $\begin{array}{l}\text { Untailed } \\
\%\end{array}$ & $\begin{array}{l}\text { Tails length } \\
\mu \mathrm{m}\end{array}$ & $\begin{array}{l}\text { Tail } \\
\text { DNA\% }\end{array}$ & $\begin{array}{l}\text { Tail } \\
\text { moment }\end{array}$ \\
\hline LA & 3 & 98 & $1.44 \pm 0.13^{\mathrm{d}}$ & 1.51 & 2.16 \\
Spir & 1.5 & 98.5 & $1.72 \pm 0.15^{\mathrm{d}}$ & 1.30 & 2.23 \\
Asp & 12 & 88 & $4.36 \pm 0.11^{\mathrm{d}}$ & 1.46 & 1.99 \\
Asp + LA & 11 & 89 & $4.07 \pm 0.15^{\mathrm{a}}$ & 3.67 & 16.81 \\
Asp + Spir & 8 & 92 & $3.26 \pm 0.20^{\mathrm{b}}$ & 2.39 & 7.78 \\
Asp + LA + & 6.5 & 93.5 & $2.35 \pm 0.20^{\mathrm{c}}$ & 2.69 & 6.32 \\
Spir & & & & &
\end{tabular}

Different superscript letters in the same column of tail length showed significance difference at $\mathrm{P}<0.05$ 
The present study was designed to investigate the possible harmful effects of aspartame induced DNA damage, inflammation, oxidative stress and molecular alterations on brain of rabbits. In the existing study oral aspartame administration to rabbits for 8 weeks resulted in significant increase in L-MDA concentration, SOD activity and decrease of GSH concentration when compared with control normal group. These results are nearly similar with the recorded data of Iman,(2011) who stated that, oral administration of ASP $(40 \mathrm{mg} / \mathrm{kg} \mathrm{b}$. wt. ) led to a significant elevation in LPO level in the liver, kidney and brain tissue and also indicated an increase in MDA level which was accompanied by a decrease in the activities of antioxidant enzymes (SOD and CAT) and GSH concentration in the liver of rat leading to degrade $\mathrm{H}_{2} \mathrm{O}_{2}$, more $\mathrm{H}_{2} \mathrm{O}_{2}$ could be converted to toxic hydroxyl radicals that may contribute to oxidative stress due to methanol metabolite from ASP. Moreover, Ashok and Sheeladevi, (2014) shown that a significant decreases in GSH concentration and glutathione reductase activity were reported in the brain of rats treated with aspartame at 100 and $500 \mathrm{mg} / \mathrm{kg}$ doses. Glutathione is decreased after repeated aspartame administration suggesting consumption of this important antioxidant defense mechanism by increased free radicals' production due to aspartame administration which theoretically can further increase the vulnerability of the brain tissue to other oxidative insults (Tilsonha, et al., 1991). Likewise, Feijó et al.(2013) exhibited that, oral administration of rats with Aspartame $(250 \mathrm{mg} / \mathrm{kg} \mathrm{b}$ wt.) significantly increased brain tissue L-malondialdehyde concentration, LPO levels and markedly decreased GSH concentration. Lipid peroxidation (LPO) is a free-radical-mediated process. In the entire rat brain regions after aspartame consumption, a marked increase in LPO was noted, which also supports the generation of free radicals. Generally, when the generation of reactive free radicals overwhelms the antioxidant defense, LPO of the cell membrane occurs. A marked increase in the LPO in the entire brain regions indicated this result and possible loss of membrane integrity (Sohal et al., 2002). Meanwhile, treatment with spirulina and alpha-lipoic acid to aspartame administered rabbits revealed a significant decrease in serum L- MDA level, decrease of SOD activity and GSH concentration when compared to aspartame group. Concerning to alpha lipoic acid $\mathrm{Li}$ et al.(2013) exhibited that alpha lipoic acid has been known to have positive effects on a wide variety of clinical conditions, which is completely consistent with its effect in decrease of the oxidative stress. Alpha-Lipoic Acid protects against oxidative stress both in peripheral tissues and central nervous system (Winiarska et al., 2008). Ying et al.(2004) demonstrated that $\alpha$-lipoic acid can eliminate superoxide anions and that this process depends on both the concentration of $\alpha$-lipoic acid and $\mathrm{pH}$. Moreover, lipoic acid is a thiol containing nucleophile, reacts with endogenous electrophiles including free radicals or reactive drug metabolites and heavy metals. On the other hand, Konickova et al.(2014) reported that, Spirulina not only had anti-proliferative effects, but also inhibited the production of mitochondrial ROS and affected glutathione redox status. Supplementation with 1 or $5 \%$ Spirulina induced GSH concentration, SOD activity and decrease LMDA level the liver in intoxicated rats. Moreover, AbdelDaim et al.(2013)described that, treatment with Spirulina significantly reduced oxidative stress and Lmalondialdehyde in aspartame treated rats. Reactive oxygen species (ROS) attack and damage molecules in biological systems, leading to oxidative stress and various disorders and diseases occur. The antioxidant potential of Spirulina species and protective effects are mediated by phycocyanins, $\beta$-carotene, and other vitamins and minerals contained within Spirulina. Moreover, Phycocyanin appears to inhibit the generation of hydroxyl and peroxyl radicals, as well as lipid peroxidation. The higher lipid peroxidation observed could be due to a lower antioxidant capacity of the cells, and oxidative stress occurs in a cell or tissue when the concentration of reactive oxygen species (ROS) generated exceeds the antioxidant capability of that cell (Bermejo et al., 2008). Also, spirulina is rich in $\beta$-carotene and the bioavailability is as good as the pure $\beta$-carotene, vitamin $\mathrm{E}$ and vitamin $C$ and selenium, and spirulina extracts could be effective against free radical induced lipid peroxidation which in turn may lead to cellular transformation ( $\mathrm{Pal}$ et al., 2010). Furthermore, Sharoud, (2015) indicated that the protective effect of spirulina platensis against paracetamol induced oxidative stress could be either direct by inhibiting lipid peroxidation and scavenging free radicals or indirect through the enhancement of the activity superoxide dismutase and the enzymatic free radicals' scavengers in the cells. These properties could be attributed to the high levels of antioxidants such as c-phycocyanin, carotenoids, vitamins, minerals, lipids, proteins and carbohydrates.

A significant up-regulation of caspase 3 and TNF- $\alpha$ gene expression level were observed in brain of Asp-treated (Asp group) rabbits as compared to the normal control group. Similarly, Dowlati et al.(2010) reported that long term of oral administration of aspartame $(75 \mathrm{mg} / \mathrm{kg} \quad$ b. wt.) significantly up regulated the expression of caspase-3 activity and TNF- $\alpha$ in brain tissue of aspartame treated rat. Also, Soffritti et al.(2006) reported that the sweetener (aspartame) could increase brain TNF- $\alpha$ potent proinflammatory cytokine that is produced by glial cells involved in various physio-pathological conditions in the CNS of rats. Moreover, Mbazima et al.(2008) reported that, free radicals play a role in the initiation of apoptotic processes. The changes recognized in the expressions of genes decreases in Bcl-2 expression and increases in Bax and caspase -3 expressions were occurred. In neurons simultaneously, they give rise to apoptosis (Thomas et al., 2000). Furthermore, increases in the expression of the proapoptotic Bax gene leads to mitochondrial release of cytochrome $\mathrm{c}$, which also triggers apoptosis. Caspases are closely associated with apoptosis. The caspase-cascade system plays vital role in the induction, transduction and amplification of intracellular apoptotic signals. A depletion of intracellular GSH has been reported to occur with the onset of apoptosis (Mbazima, etal., 2008).

Additionally, both aspartate and glutamate act as neurotransmitters in the brain, carrying information from neuron to neuron. When there is an excess of neurotransmitter, certain neurons are killed by allowing too much calcium into the cells. This influx causes excessive numbers of free radicals to build up which kill the cells. The neural cell damage that is caused by excessive aspartate and glutamate is the reason they are referred to as excitotoxins. The excite-toxins are substances, usually acidic amino acids that react with specialized receptors in the brain in such a way as to lead to destruction of certain types of neurons (Blaylock, 2002; Ho et al., 2003). In Asp administered rabbits and treated with LA and/ or Spir exhibited a 
significant down-regulation of caspase 3 and TNF- $\alpha$ gene expression as compared to Asp group. Although, Vitamin C and $\mathrm{E}$ are the best antioxidants vitamins, both have been shown to be slightly effective in different models of neurodegeneration (Davoli et al., 1986). Spirulina strongly induces antioxidant enzyme activity, helps to prevent lipid peroxidation and DNA damage, and scavenges free radicals (Abdelkhalek et al., 2015)., Similarly, Sun et al., (2011) reported that the expression of TNF- $\alpha$, NF- $\kappa \beta$ and IL-1b gene were significantly down-regulated following treatment by Spirulina. Also, Spirulina protects against neurotoxicity, hepato-nephrotoxicity and colitis in animals by reducing oxidative stress (Abdel-Daim et al., 2015).Moreover, Juarez-Oropeza et al.(2009) reported that, spirulina has both antioxidant and anti-inflammatory activities and down regulates the pro-inflammatory cytokines, which in turn might inhibit the neurodegeneration and oxidative stress thereby aids in maintaining proper brain and body health. Additionally, Ranney et al.(1976) recorded that,lipoic acid and spirulinaextract also extensively inhibit the inflammatory cascade by effectual modulation of inflammatory cytokines (TNF- $\alpha$ and IL-1), thus decrease the further exacerbation of aspartame brain injury mediated by inflammatory cytokines.

In the existing study a significant increase in DNA damage that was indicated by increase in tail length, tail DNA\% and tail moment was observed in rabbits administrated with aspartame as compared to the control group. This increased DNA damage was significantly reduced after administration of spirulina alone (G3 Spir) or in combination with LA (G2 LA) with lowest damage in combined treated group (G7 Asp+LA+Spir). Similarly, Zeynep Findıklı and ŞifaTürkoğlu (2014) shown that administration of aspartame (250 and $125 \mathrm{mg} / \mathrm{kg}$ b. wt.) was indicated by an increase in tail length and tail DNA\%. Consistent ingestion of food additives has been reported to induce toxic, genotoxic, and carcinogenic effects (Saad et al., 2014). The DNA damage induced by food additives depends on their transport across cellular/nuclear membranes, the activation and deactivation of intracellular enzymatic processes, the levels of radical scavengers, and the repair mechanisms in the target cell population. The comet assay has been used to determine the effects of these cellular processes on the amount of DNA damage induced. This assay is a powerful tool for determining genotoxicity, because it is simple and highly sensitive, has a short response time, and requires a relatively small number of cells and test substances (Čabarkapa et al., (2014).

Commonly used food sweeteners may be toxic at high concentrations in the long term. Lin et al.(2007) reported that, because DNA is a major drug target and can be damaged by harmful chemicals. The DNA damage caused by sweeteners may be associated with the generation of free radicals (reactive oxygen species), which cause DNA strand breaks and irreversible damage to proteins involved in DNA replication, repair, recombination, and transcription. Moreover, several mutagenic and genotoxic lipid peroxidation products, in particular malondialdehyde and 4hydroxy-2-nonenal, have been shown to bind to DNA and to damage it (Eder et al., 2006). In the current study treatment with spirulina platensis or and lipoic acid significantly reduced DNA damage that was indicated by comet assay in aspartame administered rabbits. These results are nearly similar to those recorded by Shirpoor et al.(2008), who reported that, alpha- lipoic acid partially alleviated the ethanol-induced DNA damage in developing hippocampus and cerebellum of rats. Hassan et al., (2012) stated that, supplementation with spirulina succeed to inhibit DNA damage as indicated by the down-regulation of Fas (Fatty acid synthase) gene expression and decreased the percentage of DNA fragmentation and micronucleated erythrocytes in aflatoxin intoxicated rats. Also, Saber et al. (2015) recorded that, co-treated rats with aluminum chloride and spirulina platensis showed a significant decrease in all parameters of DNA damage in kidney (tail percentage, tail length, DNA tail percentage, and tail moment) when compared to the aluminum chloride -treated group. The existing results were confirmed by Ismail et al., (2009) who indicated that, polysaccharides of spirulina enhanced cell nucleus enzyme activity, the process of DNA repairand the unscheduled DNA synthesis(Kaji et al., 2002).The anti-genotoxic effect of spirulina may be related to its contents of phycocyanin and phycocyanobilin which also have strong anticyclooxygenase-2, antioxidant activity to scavenger peroxidinitrite and reduce peroxynitrite (OONO-) induced oxidative damage to DNA (Bhat and Madyastha, 2001).

\section{CONCULSION}

In conclusion, the results of the present work revealed that Spirulina and alpha lipoic acid alleviates the harmful effects of aspartame on brain tissue of rabbits. Also, Spirulina and alpha lipoic acid has a protective antioxidant role in restoration of oxidative stress, a strong anti-inflammatory and anti-apoptotic effects on aspartame-induced brain damage. In this regard the current study has brought a convincing indication preferring the usage of natural antioxidants like spirulina and alpha lipoic acid as a protective strategy against toxicity induced by aspartame.

\section{REFERENCES}

1. Abdel-Daim, M.M.; Abuzead, S.M.andHalawa, S.M. 2013 Protective role of Spirulina platensis against acute deltamethrin-induced toxicity in rats. PLoS ONE 8(9):e72991.

2. Abdelkhalek, N.K.; Ghazy, E.W. and Abdel-Daim, M.M. 2015. Pharmacodynamic interaction of Spirulina platensis and deltamethrin in freshwater fish Nile tilapia, Oreochromis niloticus: impact on lipid peroxidation and oxidative stress. Environ Sci Pollut Res Int 22(4):3023-3031.

3. Abdel-Salam, O.M.; Salem, N. A.; El-Shamarka M.E.; Hussein JS, Ahmed N.A.; AND El-Nagar, M.E. 2012. Studies on the effects of aspartame on memory and oxidative stress in brain of mice. Eur Rev Med Pharmacol Sci. Dec;16(15):2092101

4. Ashok, I., Sheeladevi R. 2014. Biochemical responses and mitochondrial mediated activation of apoptosis on long-term effect of aspartame in rat brain. Redox Biol. 2:820-831.

5. Barceloux, D.G.; Bond, G.R.;Krenzelok, E.P.; Cooper H, Vale J.A. 2002.American Academy of Clinical Toxicology practice guidelines on the treatment of methanol poisoning. Clin.Toxicol., 40, 415.

6. Beg, A. A.; Finco, T. S.; Nantermet, P. V., and Baldwin, J.r 1993. Tumor necrosis factor and interleukin-1 lead to phosphorylationand loss of $\mathrm{I} \kappa \mathrm{B} \alpha$ : a mechanism for NF- $\kappa \mathrm{B}$ activation. Molecular and Cellular Biology13 (6): 3301-3310.

7. Bermejo, P., Pisero, E. and Villar, M. 2008. Iron-chelating ability andantioxidant properties of phycocyanin isolated from a proteanextract of Spirulinaplatensis. Food Chem $110(2): 436-445$ 
8. Beutler E, Duro, O, ; Kelly B.M; 1963.Improved method for the determination of blood glutathione. J. Lab. Clin. Med., 61, 882-888

9. Bhat, V.B. and Madyastha, K.M. 2001. Scavenging of peroxynitrite by phycocyanin and phycocyanobilin from Spirulina platensis: protection against oxidative damage to DNA. Biochem. Biophys. Res. Common., 285: 262-266.

10. Blaylock, R.L. 2002. Aspartame, Monosodium glutamate and other Excitotoxins and the Hypothalamus, From: "Russell M.D.", Borlongan, C.V., Kanning, K., Poulos, T.B., Cahill, D.W., and Sanberg, P.R. Free radical damage and oxidative stress in Huntington's disease, J. Fla. Med. Assoc., 83, 335341.

11. Boldin, M.P.;Varfolomeev, E.E.;Pancer, Z.; Mett, I.L.;Camonis, J.H.; Wallach, D. 1995.A novel protein that interacts with the death domain of Fas/APO1 contains a sequence motif related to the death. J Biol Chem., 270(14):7795-7798

12. Butterfield, D.A, ; Stadtman, E.R. 1997. Protein oxidation processes in aging brain. Adv, Cell Aging Gerontol, 2: 161191

13. Čabarkapa A, Živković L, Žukovec D, Djelić N, Bajić V, Dekanski D, Spremo-Potparević, B. 2014. Protective effect of dry olive leaf extract in adrenaline induced DNA damage evaluated using in vitro comet assay with human peripheral leukocytes. Toxicol. In Vitro 28:451-456

14. Chaudiere, J, Ferrari-iliou, R. 1999.Intracellular antioxidants: from chemical to biochemical mechanisms. Food ChemToxicol, 37, 949-962

15. Colla, L.M.;Muccillo-Baisch, A.L.; Costa, J.A.V 2008.Spirulina platensis Effects on the Levels of Total Cholesterol, HDL and Triacylglycerols in Rabbits Fed with a Hypercholesterolemic Diet. Brazilian Arch Biol and Technol.; 51:405-411.

16. Coulombe R.A, Sharma R.S. 1986.Neurobiochemical alterations induced by the artificial sweetener aspartame (Nutrasweet). ToxicolApplPharmacol, 83: 79-85

17. Davoli, E, Cappellini L, Airoldi L, Fanelli R. 1986. Serum methanol concentration in rats and in men after a single dose of aspartame. Food ChemToxicol 24: 187-189

18. Davoli, E: 1986.Serum methanol concentrations in rats and in men after a single dose of aspartame. Food Chem. Toxicol.;24, 187-189.

19. Dowlati, Y., Herrmann, N., Swardfager, W., Liu, H., Sham, L., Reim, E.K., .2010. A Meta-Analysis of Cytokines in Major Depression. Biological Psychiatry, 67(5):446-457.

20. Eder, E.; Wacker, M.;Lutz, U.;Nair, J.;Fang, X.;Batsch, H.;Beland, F.A.;Schlatter, J. and Lutz, W.K. (2006). Oxidative stress related DNA adducts in theliver of female rats fed with sunflower, grapeseed, olive or coconut oil supplemented diets. Chem. Biol. Interact., 159: 81-89.

21. EFSA, 2006.EFSA assesses new aspartame study and reconfirms its safety. European Food Safety Authority. European Ramazzini Foundation, Bologna, Italy. 196, 117.

22. Gougeon R, Spidel M, Lee K, Field CJ. 2004. Canadian diabetes association national nutrition committee technical review: Non-nutritive intense sweeteners in diabetes management. Canadian J Diabetes, 28(4):385-399

23. Halliwell B, Gutteridge, JMC. 1985. Oxygen radicals and nervous system. Trend Neurosci, 8: 22-26

24. Halliwell B, Gutteridge, J.M.C. 1999.Oxidative stress: adaptation, damage, repair and death. In: Free Radicals in Biology and Medicine, third ed. Oxford University Press, Oxford, , pp. 246-349.

25. Harper AE. 1984. Phenylalanine metabolism, In Stegink LD, Filer LJ Jr eds. Aspartame, physiology and biochemistry. Marcel Dekker, Inc., pp. 77-109.

26. Hassan, A.M.; Abdel-Aziem, S.H. and Abdel-Wahhab, M.A (2012). Modulation of DNA damage and alteration of gene expression during aflatoxicosis via dietary supplementation of Spirulina (Arthrospira) and Whey protein concentrate. Ecotoxicol Environ Saf 79:294-300
27. Ho, PI., Daniela Ortiz, Rogers E, Shea., T, 2003.Multipe aspects of Homocysteine nurotoxicty, kinase hyperactivation and DNA damge, Journal of Neuroscience Research, 70,694702 .

28. Hull Janet Starr, 2002. Sweet Poison How The World's Mos Popular Artificial Sweetener Is Killing Us - My Story - , New Horizon Press, ISBN; 0-88282- 164-4.

29. Ilhan A, Gurel A, Armutcu F, Kamisli S, Iraz M 2005.Antiepileptogenic and antioxidant effects of Nigella sativa oil against pentylenetetrazolinduced kindling in mice. Neuropharmacol., 49: 456-464

30. Iman, M. Mourad. 2011. Effectof aspartame on some oxidative stress parameters in liver and kidney of rats." Afr.J. Pharm.Pharmacol. 5 (6): 678 -862.

31. Ismail, M.F.; Ali, D.A.; Fernando, A.; Abdraboh, M.E.; Gaur, R.L.; Ibrahim, W.M.; Raj, M.H.G.; and Ouhtit. A. (2009).Chemoprevention of Rat Liver Toxicity and Carcinogenesis by Spirulina. International Journal of Biological Sciences., 5 (4): 377-387.

32. Itoh, N., Nagata, S., 1993. A novel protein domain required for apoptosis. Mutational analysis of human Fasantigen.J. Biol. Chem. 268, 10932-10937domain.J. Biol. Chem. 270, 7795-7798.

33. Juarez-Oropeza M.A, Mascher D, Torres-Duran P.V, Farias J.M, Paredes-Carbajal M.C., 2009. Effects of Spirulina on vascular reactivity. J Med Food 12(1): 15-20.

34. Kaji, T., Fujiwara, Y. and Inomata, Y. 2002. Repair of wounded monolayers of cultured bovine aortic endothelial cells is inhibited by calcium spirulina, a novel sulfated polysaccharide isolated from Spirulina platensis. Life Sci., 70:1841-1848

35. Koníc`ková, R.; Van`ková, K. and Vaníková, J. 2014. Anticancer effects of blue-green alga Spirulina platensis, a natural source of bilirubin like tetrapyrrolic compounds. Ann Hepatol 13(2):273-283.

36. Krebs M.O. 1992. Excitatory amino acids: a new class of neurotransmitters: pharmacology and functional properties. Encephale., 18 (3): 271-279

37. Li R, J.i, W, Pang J, 2013.Alpha-lipoic acid ameliorates oxidative stress byincreasing aldehyde dehydrogenase-2 activity in patients with acute coronary syndrome. The Tohoku J.Experim.Med.229:45-51.

38. Lin., A.J, Zhang, X, Chen M, Cao, Q., 2007.Oxidative stress and DNA damages induced by cadmium accumulation. J. Environ. Sci. (China) 19:596-602.

39. Magnuson B.A.; Burdock G.A.;Doull J, Kroes R.M.; Marsh, G.M.;Pariza M.W.; Spencer, P.S.; Waddell, W.J.; Walker R, Williams G.M.; 2007.Aspartame: A safety evaluation based on current use level, regulation, and toxicological and epidemiological studies. Critical Rev Toxicol., 37(8): 629727.

40. Mapuskar, K.A., 2019. Utilizing Superoxide Dismutase Mimetics to Enhance Radiation Therapy Response While Protecting Normal Tissues. in Seminars in radiation oncology. Elsevier.

41. Mbazima, V. G.;Mokgotho, M. P.; February, F., Rees, D. J. G.;\&Mampuru, L. J. M. 2008. Alteration ofBax-to-Bcl - 2 ratio modulates the anticancer activity of methanolicextract of ommelinabenghalensis (Commelinaceae) in Jurkat $\mathrm{T}$ cells. African Journal of Biotechnologyof the American Association of Neuroscience Nurses , 37 (2), $102-107$.

42. Nishikimi, M., Roa, N.A., Yogi, K. 1972. Measurement of superoxide dismutase Biochem. Bioph. Res. Common., 46, $849-854$.

43. Ohkawa, H., Ohishi, W., Yagi, K. 1979. Assay for lipid peroxides in animal tissues by thiobarbituric acid reaction.AnalBiochem 95(2):351-8.

44. Olney J.W.; Farber, N.B, Spitznage, E, Robins L.N. 1996. Increasing Brain Tumor Rates: Is There a Link to Aspartame?, J. NEUROPATH. EXP. NEUR., 55, 1115-1123.

45. Pardridge, W.M. 1986.Potential effects of the dipeptide sweetener aspartame on the brain, in RJ Wurtman and JJ 
Wurtman, eds., Nutrition and the Brain, vol. 7, New York, Raven Press, pp. 199-241.

46. Pardridge W.M. 1979. :Regulation of amino acid availability to brain: selective control mechanisms for glutamate, in LJ Filer et al. eds., Glutamic acid, Advances in Biochemistry and Physiology, Raven Press, New York, , pp. 125-137.

47. Ranney, J.A.; Opperman, E. Muldoon, F.G.; McMahon, 1976 Comparative meta-bolism of aspartame in experimental animals and humans, J. Toxicol. Environ.Health 2 (2) 441e451.

48. Reznick AZ, Packer L. 1993. Free radicals and antioxidants in muscular neurological diseases and disorders. In: Poli G, Albano E, Dianzani MU. eds., Free Radicals: from Basic Science to Medicine. BirkhäuserVerlag, Basel, , pp. 425-437.

49. Saad, A. Khan, F.A.: Hayee A, Nazir, M.S. 2014. Areview on potential toxicity of artificial sweeteners vs safety of stevia:A Health natural biology, Agriculture and Healthcare 4(15):112.

50. Saber,T.M.; Elgaml,S.A.; Ali,H.A. and Saleh, A.A.2015. Protective effect of Spirulina platensis against aluminiuminduced nephrotoxicity and DNA damage in rats, Toxicological \& EnvironmentalChemistr.,97:(8)1113-1123.

51. Salvi, V., 2019. Cytokine Targeting by miRNAs in Autoimmune Diseases. Front. Immunol., 10 (15):1-10

52. SAS . 2008. Statistical analysis system : User's guide v. 9.2, Inst. Inc., Cary N.C., USA.

53. Shirpoor, A.; Minassian, S.; Salami, S.; Khadem-Ansari, H. M. and Yeghiazaryan, M. (2008). Alpha - Lipoic Acid Decreases DNA Damage and Oxidative Stress Induced by Alcohol in the Developing Hippocampus and Cerebellum of Rat. Cell PhysiolBiochem ;22:769-776

54. Siesjo SK, Agardh CD, BengtssonF.1989. Free radicals and brain damage.CerebrovascBrain Metab Rev, 1: 165-211

55. Singh, N., McCoy, M., Tice, R, 1988. A simple technique for the quantitation of low levels of DNA damage in individual cells. Exp Cell Res 175: 184-191.

56. Soffritti, M., Belpoggi, F., DegliEsposti, D., Lambertini, L., Tibaldi, E., Rigano, A., 2006.First experimental demonstration of the multi. Health Perspect. 115, 1293-1297.
57. Soffritti, M., Belpoggi, F., Tibaldi, E., Esposti, D. D., \&Lauriola, M. 2007. Life - span exposure to low doses of aspartame beginning during prenatal life increases cancer effects in rats. Environmental Health Perspectives , 115 (9), $1293-1297$.

58. Sohal R.S.;Mockett, R.J.;O.r.r, W.C. 2002. The main purpose of this article is to provide a critical overview of the currently available $1 ; 33$ (5):575-86.

59. Sun J-P, Han Q, Zhang X-Q,. 2014. Investigations on the degradation of aspartame using high-performance liquid chromatography/tandem mass spectrometry. ChinChem Lett.; 25: $1259-1264$

60. Tilsonh, A. Hongjs, Sobotkatj. 1991.High doses of as-partame have no effects on sensorimotor functionor learning and memory in rats. NeurotoxicolTeratol.; 13: 27-35.

61. Thomas, A., Giesler, T., \& White, E. 2000.p53 mediates bcl2 phosphorylation and apoptosi $\mathrm{s}$ via activation of the Cdc42/JNK1 pathway. Oncogene ,19(46), 5259- 5269.

62. Turner, N. W.,Subrahmanyam, S., Piletsky, S. A. 2009. Analytical methods for determination of mycotoxins: A review. Analytica Chimica Acta, 632(2), 168-180.

63. Winiarska, K., Malinska, D., Szymanski, K., Dudziak, M.,Bryla, J., 2008.Lipoic acid ameliorates oxidative stress and renal injury in alloxan diabetes rabbits. Bioch.90: 450-459.

64. Ying L.; Zhao, Y.; Yu, W. and Jiang, S. (2004).Scavenging ability on ROS of alpha-lipoic aicd (ALA). Food Chem. 84:563-567.

65. Yoshikawa, T.and Naito, Y. 2002. What is oxidative stress JMAJ45(7):271-276

66. Zeynep., F. and Sifa, T. 2014.Determination of the effects of some artificial sweeteners on human peripheral lymphocytes using the comet assay. J. Toxicol. Environ. Health Sci. Vol. 6(8), pp. 147-153.

67. Zheng, J.; Inoguchi, T.; Sasaki, S.; Maeda, Y.; McCarty, M.F.; Fujii, M.; Ikeda, N.; Kobayashi, K.; Sonoda, N. and Takayanagi, R. 2013. Phycocyanin and phycocyanobilin from Spirulina platensis protect against diabetic nephropathy by inhibiting oxidative stress. Am J PhysiolRegulIntegr Comp Physiol., 304(2):R110-R130. 